\title{
Anita Chan (ed.), Chinese Workers in Comparative Perspective,
}

Ithaca, NY, Cornell University Press, 2015, 296 pp.

\section{Ming-sho Ho}

\section{OpenEdition}

\section{Journals}

Electronic version

URL: http://journals.openedition.org/chinaperspectives/6877

DOI: $10.4000 /$ chinaperspectives. 6877

ISSN: 1996-4617

\section{Publisher}

Centre d'étude français sur la Chine contemporaine

Printed version

Date of publication: 1 December 2015

Number of pages: 73-74

ISSN: 2070-3449

\section{Electronic reference}

Ming-sho Ho, "Anita Chan (ed.), Chinese Workers in Comparative Perspective, », China Perspectives [Online], 2015/4 | 2015, Online since 01 January 2017, connection on 22 September 2020. URL : http:// journals.openedition.org/chinaperspectives/6877 ; DOI : https://doi.org/10.4000/chinaperspectives. 6877 
ence being biological. Indeed, Yinde Zhang has produced a detailed study of each work in its imaginary dimension, looking at the tension between the real and the supernatural, the rational and the fantastic. The aim of the critique is to show that, by depicting the violence of the body, Mo Yan questions the connection between the individual and history and attempts, perhaps, to restore a form of vital power or humanism to a fiction that speaks of the body and of life: a biofiction.

The study first looks at The Republic of Wine: $A$ Novel, a virulent satire of an abject society. Indeed, this was the first of Mo Yan's novels to recount the violence of relations between the individual and the state, in the metaphorical form of cannibalism "to textualise the abjection, this rejection outside the body" (p. 118). The omnipresence of the lower functions of the body allows a primitive power to re-emerge, blowing away all notions of decorum. Yinde Zhang next considers Big Breasts \& Wide Hips, which draws a paradoxical picture of the motherland, in which jintong's mother symbolises China's sacrifices over the course of the series of destructive utopias it has experienced through history. Bodily violence is once more the theme in Sandalwood Death, which approaches the subject through a critique of a violated and colonised territory; finally, this biological dimension of the writing finds expression in Frog, the explicit theme of abortion, and the treating of the body as a commodity. In this case, the question of the body is once more linked to the earth, because the novel reveals the negligence of successive policies blighted by utilitarianism. Yinde Zhang shows that, from Mo Yan's point of view, from communism to liberalism, history is nothing more than a cycle that keeps repeating, an inevitable return of alienations of the body and mass executions.

After a brief conclusion that shifts the emphasis of the question of Mo Yan's controversial commitment towards a subversive writing policy, the end of the book offers an insight into the reception of the writer in France, both in the press and in the world of academic research, which makes it possible, in hindsight, to embrace the originality of Yinde Zhang's viewpoint. Instead of appraising Mo Yan's work through the prism of a culturalist or exotic vision, it considers it rather by studying how this "fictional world, with its autobiographical, memory, and mythical dimensions, breathes life into realistic and fabulous figures, while mixing in violence, cruelty, animality, the carnavalesque, the grotesque, irony, and humour. The variety of aspects in the work thus corresponds to its polymorphic and transgeneric nature: a web-like organisation is worked through the texts and genres, linking them thanks to a meaningful collection of repetitions and variations" (p. 58). Similarly, Yinde Zhang's book is organised around the motifs of the body and territory, thus sketching a literary map of Mo Yan's world.

\section{Translated by Will Thornely.}

I Fanny Fontaine studied at ENS Lyon University and is a PhD candidate in comparative literature at Sorbonne Nouvelle UniversityParis 3 (fangui19@gmail.com).

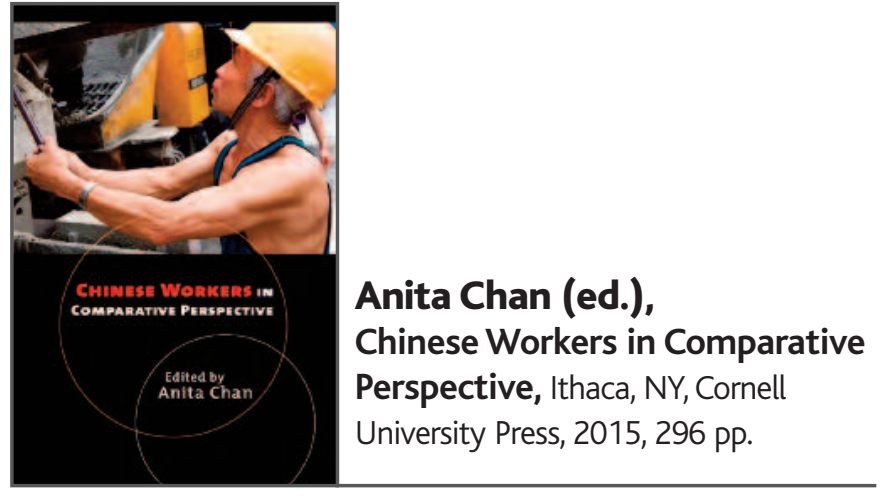

\section{MING-SHO HO}

C hina watchers generally agree that successful economic development through low-wage export has shown signs of exhaustion. Since the Labour Contract Law came into effect in 2008, labour costs have risen considerably, squeezing the profit margins of export-oriented manufacturers. Migrant workers' rights consciousness has surged, as witnessed by the Honda strike and the much publicised wave of suicides at Foxconn (a Taiwanese electronics maker) in 2010, and the strike at Yue Yuen (a Taiwanese footwear maker) in 2014, all taking place in Guangdong Province, nicknamed "China's California" for its economic significance. The visible slow-down in GDP growth has also cast doubt on the viability of the current strategy to maintain political acquiescence with improving living standards. Chinese Workers in Comparative Perspective is an edited volume that provides timely and comparative insight into how the working class has experienced the recent major transformation.

Anita Chan, the editor of this volume and an Australia-based veteran observer of China's workers, persuasively contends that it is time to move beyond "the fallacy of exceptionalism," since what is happening in contemporary China can also be found elsewhere. The methodological refusal to treat China's working class as a special case helps to demystify the official pretension to create "socialism with Chinese characteristics," since, as the introductory chapter eloquently argues, workers are exploited as much there as in other capitalistic countries, if not more. There is another unexplored implication. This contextualising research strategy is instrumental in debunking some naive but fashionable and influential expectations that China will evolve into a balanced and harmonious developmental pattern (1) or a unique path that combines political stability and economic growth. (2) As in nineteenth-century Britain, the contemporary world factory of China is no less ruthless to the producers who supply the globe with what millions need, the irony being that it is ruled by a party that retains nominal allegiance to the historical mission of classical Marxism.

Originating from a 2011 conference, this volume offers a sufficiently updated diagnosis of China's working class. The foreign-funded factories in maritime provinces continue to rely on labour supply from the rural hinterland, and have recently begun to hire second-generation migrant workers. That the new generation is more city-bound and less likely to identify themselves as temporary sojourners has deeper implications for class politics in the years to come. Massive lay-offs in state-owned enterprises and

1. Giovanni Arrighi, Adam Smith in Beijing: Lineages of the 21st Century, London, Verso, 2009.

2. Jacques Martin, When China Rules the World: The End of the Western World and the Birth of a New Global Order, New York, Penguin, 2009. 
the ensuing worker protests have already occurred; in fact, the state-sector share of the working population has stabilised since the 2007-2008 global financial crisis, although the new entrants tend to be casual workers. Taiwanese and Hong Kong firms specialising in labour-intensive garments and electronics continue to operate in the notorious sweatshop fashion with low wages and long hours. Despite some success in industrial upgrading, repetitive, monotonous, and low-skilled assembly line tasks continue to make up the bulk of job offers in these firms.

Chinese Workers in Comparative Perspective also sheds light on the difficult but hitherto largely successful imperatives of reconciling the conflicting demands of encouraging investment and protecting workers, which the highly-adaptive Chinese Communist regime has mastered into a political art. The Communist-controlled All-China Federation of Trade Unions has gradually been given a larger role, and its rank-and-file membership has actually increased since the turn of century. Except in the few cases where union leaders were democratically elected due to grassroots activism, "yellow unions" predominate at the enterprise level, which nevertheless has not prevented local-level unionists from playing a more assertive role in mediating industrial disputes. Persistent effort in labour legislation since the 1990s has substantially improved workers' legal and economic status without empowering them politically. In spite of the proverbial official corruption and collusion with business, the Chinese government has not embraced an exclusionary strategy toward the working class, which has helped contain class antagonism within a manageable scope.

There are several chapters in which cross-national comparisons offer valuable insight into some contemporary puzzles. Both Japanese and German carmakers operated joint ventures in China, but the former have been more prone to industrial disputes, not only because Japanese firms are easy targets of nationalistic sentiment, but also because they are less embedded in local supply chain. As with Taiwan 30 years ago, China's labour NGOs have offered legal aid to victimised workers. Taiwanese labour activists were organisationally linked to the democratic movement, and their political strength enabled them to build new labour unions free of government control, whereas their contemporary Chinese counterparts continue to chafe under the watchful authorities. Both Russia and China embarked on post-socialist transition in the 1980s; the sudden collapse of Russia's Communist regime allowed union leaders to assert their political independence and enabled alternative unionism, whereas the post-Tiananmen CCP strengthened its control over unions. Vietnam is another transitional economy with entrenched Communist rule. Compared with Chinese workers, Vietnamese are less overworked and but also paid less. While Vietnamese unionists have engaged in sector-specific collective bargaining, Chinese workers are more likely to resort to wildcat strikes to improve their treatment. An interesting chapter on soccer ball production brings India, Pakistan, and China together, with the sombre conclusion that the corporate social responsibility campaign has been largely ineffective, since local manufacturers have been able to shield their problematic production from public scrutiny by using home-based child labour in South Asia and prison labour in China.

This volume demonstrates the rich repertoire of comparative labour studies, which can proceed on the firm, sectoral, regional, or national level. Methodologically speaking, most comparativists adopt the design of "most similar system method" by selecting more similar country cases. In this regard, two chapters that compare the effect of neoliberal globalisation in the United States and the legalisation of strikes in Australia appear unex- pected and unconventional, since China shares little common ground with these two advanced capitalist countries. Moreover, with the on-going economic transition from world factory to world market, service-sector employment is quickly eclipsing that in manufacturing. This volume mostly looks at factory manual workers, arguably the classical research topic in labour research; more studies are needed on service workers and skilled professionals in order to bring out a fuller picture of China's working class.

I Ming-sho Ho is professor at the Department of Sociology, National Taiwan University (mingshoho@gmail.com).

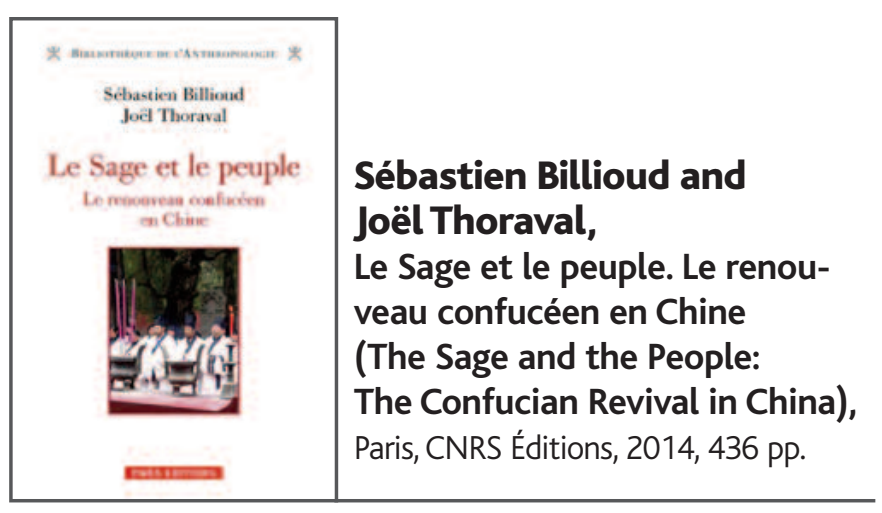

\section{川 ZHE}

1 his book, which has been recently translated into English, (1) sets out a new paradigm for studies on Confucianism. Unlike currently available works, which despite their high quality tend to reduce the complex "Confucian" phenomenon (an all too accommodating, not to say ambiguous, label) to various partial aspects such as philosophy, ethics, official ideology, or worship practices, this book stands out for its approach to the phenomenon as a whole, which enables it to avoid reductionism. Based on ethnographic material garnered over several years' research in China, Hong Kong, and Taiwan, the two authors provide a panoramic description of the many social expressions of Confucianism in the first decade of the twenty-first century, along with a critical analysis of their moral and political preconditions. The two authors call these manifold expressions "popular Confucianism," which is a term borrowed from Chinese activists but in no way refers to a purely anti-elitist or simply unofficial movement. On the contrary, elitist initiatives and governmental interventions are closely involved and are therefore given equal weight by the two authors. Their insistence on the "popular" aspects corresponds above all to their purely heuristic stance. This enables them to take into account the polarity of a "popular" component, which on the one hand comprises a value term and a complex of many-facetted forces, and on the other the image of a "sage," which having been refracted through many cultural inputs in the past and badly abused in the twentieth century, continues to haunt Chinese modernity. But there is also an anthropological ambition here: to study "the confrontation of individuals from popular social milieus with their image of Confucius and, in

1. Sébastien Billioud and Joel Thoraval, The Sage and the People:The Confucian Revival in China, Oxford, Oxford University Press, 2015, 352 pp. 